Maloney, K.M., et al., 2021, New multicellular marine macroalgae from the early Tonian of northwestern Canada: Geology, v. 49, https://doi.org/10.1130/G48508.1

\title{
New multicellular marine macroalgae from the early Tonian of northwestern Canada
}

\section{DESCRIPTION OF METHODS \\ Field methods}

In order to constrain the paleoenvironment of these fossils, we measured three stratigraphic sections through the fossiliferous interval. We sampled shale slabs $(\mathrm{n}=90$; containing up to 100 macrofossil specimens per slab), collected from seven distinct horizons within the Dolores Creek Formation (Figure 1). All samples will be reposited with the Royal Ontario Museum in Toronto and the Yukon Geological Survey. Although many samples were obtained from scree, seventeen shale slabs were collected in situ and exhibit a range of preservation of individual fossils $(n=250)$.

\section{Fossil Measurements}

Fossil specimens were each cleaned and prepared for morphological study. Digital photographic images were processed through Image J software (Rasband and U.S. National Institutes of Health, 1997), allowing for detailed linear measurements (length and width of specimens, length and width of segments, and number of segments; see Data S2) where visible. Where present, the smaller size class fossils were measured from wellpreserved samples.

\section{Analytical microscopy}

Macrofossils were analyzed and characterized for their preservational quality and morphological complexity. Selected specimens were analyzed using scanning electron microscopy (SEM), energy dispersive x-ray spectroscopy (EDS), and tomographic x-ray microscopy $(\mu \mathrm{CT})$ at the University of Missouri X-ray Microanalysis Core. The SEM and EDS analyses were conducting using a Zeiss Sigma 500 variable pressure system equipped with dual, co-planar Bruker XFlash spectrometers. All SEM and EDS analyses were conducted at identical beam and chamber conditions, including a $20 \mathrm{keV}$ beam accelerating voltage, $40 \mathrm{nA}$ high current mode, $60 \mu \mathrm{m}$ aperture, and $20 \mathrm{~Pa}$ chamber pressure with a $99.999 \%$ nitrogen atmosphere. Z-contrast imaging was conducted using a high-definition 5-segment backscatter detector, and a cascade current detector was used for secondary electron imaging in low vacuum. The EDS elemental mapping was used to characterize the composition of the specimens, with both detectors in tandem, 360 seconds live-time, and using a $120 \mu \mathrm{m}$ aperture to provide higher x-ray count rate. A specimen with three-dimensional preservation was further analysed through $\mu \mathrm{CT}$ (Zeiss Xradia 510 Versa) to observe any preserved three-dimensional structure. The operating conditions were as follows: $80 \mathrm{kV}$ source voltage, $7 \mathrm{~W}$ source power, LE3 filter, $0.4 \mathrm{X}$ objective, $4.5 \mathrm{sec}$ exposure, 2001 projections at 360 degrees, voxel size $11.09 \mu \mathrm{m}$.

\section{Re-Os Geochronology}

Samples for Re-Os geochronology (GL-1408) were collected from a black shale interval between stromatolitic dolostone in the upper Dolores Creek Formation, $\sim 20$ meters below the contact with the conformably overlying Black Canyon Creek Formation south of Tarn Lake and $6.7 \mathrm{~km}$ to the northwest of the fossil locality $\left(64^{\circ} 43.83^{\prime}, 133^{\circ} 17.84^{\prime} \mathrm{W}\right.$; Fig S3). Samples were excavated from the outcrop along strike from a narrow stratigraphic range, 
as well as vertical profile between 121.6 and $123.2 \mathrm{~m}$ stratigraphic height. To remove any weathered surfaces, samples were cut with a diamond-tipped lapidary saw blade and polished with a diamond pad to remove any metal contamination from the saw blade. Then 30-50 g aliquots were crushed to a fine powder (ca. $30 \mu \mathrm{m})$ using a SPEX zirconia ceramic puck and grinding container to homogenize each sample. The Re-Os analytical protocol was carried out at the Durham Geochemistry Centre (Source Rock and Sulfide Geochronology and Geochemistry, and Arthur Holmes Laboratories) during 2014 following established methodologies (cf.(Selby and Creaser, 2003; Cumming et al., 2013). In brief, sample powders of $\sim 1 \mathrm{~g}$ were digested and equilibrated with $\mathrm{Cr}^{\mathrm{VI}}-\mathrm{H}_{2} \mathrm{SO}_{4}$ and a known quantity of a mixed ${ }^{185} \mathrm{Re}+{ }^{190} \mathrm{Os}$ tracer solution. Purification of the Re and Os fractions were achieved by solvent extraction, microdistillation, and anion chromatography. The isotope compositions of Re and Os were determined via negative thermal ionization mass spectrometry (NTIMS) using a ThermoScientific TRITON mass spectrometer. Analytical blanks were $10.0 \pm 3.0 \mathrm{pg}$ for Re and $0.06 \pm 0.15 \mathrm{pg}$ for Os ( $1 \mathrm{SD}, \mathrm{N}=3$ ), with an average ${ }^{187} \mathrm{Os} /{ }^{188} \mathrm{Os}$ value of $0.25 \pm 0.05$. The results for standard in-house solutions (50 pg aliquot of DROsS; $125 \mathrm{pg}$ Re std aliquot) are the similar to those reported for the analytical period and recommended values (Nowell et al., 2008; Du Vivier et al., 2014) $\left({ }^{185} \mathrm{Re} /{ }^{187} \mathrm{Re}=0.598021 \pm 0.00110 ;{ }^{187} \mathrm{Os} /{ }^{188} \mathrm{Os}=0.160890 \pm\right.$ $0.00061,1 \mathrm{SD}, \mathrm{N}=5$ ). Uncertainties for ${ }^{187} \mathrm{Re} /{ }^{188} \mathrm{Os}$ and ${ }^{187} \mathrm{Os} /{ }^{188} \mathrm{Os}$ are determined by full error propagation of uncertainties in Re and Os mass spectrometer measurements, blank abundances and isotopic compositions, spike calibrations, and reproducibility of standard Re and Os isotope values.

The Re-Os age was determined through regression of Re-Os data in ${ }^{187} \mathrm{Os} /{ }^{188} \mathrm{Os}$ vs. ${ }^{187} \mathrm{Re} /{ }^{188}$ Os space using $2 \sigma$ level absolute uncertainties and the error correlation, rho, using the benchmark "Isoplot" algorithm (Ludwig, 2011) and the Monte Carlo sampling method for error propagation with the ${ }^{187} \mathrm{Re}$ decay constant of $1.666 \mathrm{e}^{-11} \pm 5.165 \mathrm{e}^{-14} \mathrm{a}^{-1}$ (Smoliar et al., 1996) using the beta version of Isochron program (Li et al., 2019).

\section{SUPPLAMENTAL TEXT}

\section{Re-Os results}

Regression of Re-Os data from the Dolores Creek Formation yields a Model 1 Re-Os isochron age of $896 \pm 45 \mathrm{Ma}(2 \sigma, n=5$, mean square of weighted deviates [MSWD] $=$ 0.92; uncertainty with and without the decay constant uncertainty is 44.67 and $44.76 \mathrm{Ma}$, respectively) with an initial ${ }^{187} \mathrm{Os} /{ }^{188} \mathrm{Os}$ composition $\left(\mathrm{Os}_{\mathrm{i}}\right)$ of $0.38 \pm 0.09$ (Fig. S1; Data S2; Table S1). This calculated age is essentially identical to the Monte Carlo approach ( $898 \pm 68$ Ma including both analytical and model age uncertainties; Fig. S1). The greater uncertainty in the age derived by the Monte Carlo approach further illustrates that a Model 1 Isoplot outcome underestimates the total age uncertainty arising from only considering analytical uncertainties (Li et al., 2019). Here, we consider the best estimate of the depositional age of the Dolores Creek Formation to be $898 \pm 68 \mathrm{Ma}$. The linear correlation between ${ }^{187} \mathrm{Re} /{ }^{188} \mathrm{Os}$ and ${ }^{187} \mathrm{Os} /{ }^{188} \mathrm{Os}$ and lack of a linear correlation between ${ }^{187} \mathrm{Os} /{ }^{188} \mathrm{Os}$ and $1 /{ }^{192} \mathrm{Os}$ indicates that the uncertainty in this age can be attributed to variation in the ${ }^{187} \mathrm{Os} /{ }^{188} \mathrm{Os}$ of basin waters throughout the depositional timespan recorded by the sampled stratigraphic intervals rather than open-system behavior of the Re-Os isotope system. 
Uncertainty with and without the decay constant uncertainty is 44.67 and $44.76 \mathrm{Ma}$, respectively (Fig. S1). The greater uncertainty in the age derived by the Monte Carlo approach further illustrates that a Model 1 Isoplot outcome underestimates the total age uncertainty arising from only considering analytical uncertainties (Li et al., 2019). The linear correlation between ${ }^{187} \mathrm{Re} /{ }^{188} \mathrm{Os}$ and ${ }^{187} \mathrm{Os} /{ }^{188} \mathrm{Os}$ and lack of a linear correlation between ${ }^{187} \mathrm{Os} /{ }^{188} \mathrm{Os}$ and $1 /{ }^{192} \mathrm{Os}$ indicates that the uncertainty in this age can be attributed to variation in the ${ }^{187} \mathrm{Os} /{ }^{188} \mathrm{Os}$ of basin waters throughout the depositional timespan recorded by the sampled stratigraphic intervals rather than open-system behavior of the Re-Os isotope system.

\section{Stratigraphic overview}

The Dolores Creek Formation is the lowermost of three formations comprising the Hematite Creek Group in the Wernecke Mountains, Yukon (Fig. 1, S2, S3; (Turner, 2011)). The Dolores Creek Formation is overlain conformably by the Black Canyon Creek Formation, which in turn is transitional above into the Tarn Lake Formation (Fig. 1). Together, these three formations comprise a single shoaling-upward sequence (Fig. 1; (Turner, 2011)). The Hematite Creek Group unconformably overlies the late Mesoproterozoic Pinguicula Group, which comprises shales and dolostone. It is overlain by the Katherine Group, which consists of $\sim 1.5 \mathrm{~km}$ of predominantly sandstone, subordinate siltstone and shale, and minor carbonate. In the Wernecke Mountains, the contact between the upper Hematite Creek Group (Tan Lake Formation) and lowermost Katherine Group is gradational. In the Mackenzie Mountains (Northwest Territories), the Katherine Group is overlain by the thick $(>2 \mathrm{~km})$ Little Dal Group, which consists mainly of dolostone (Fig. S2). Only the lowermost $300 \mathrm{~m}$ of the Little Dal Group is preserved in the Wernecke Mountains, where it is deeply truncated by an angular unconformity developed beneath Cryogenian strata. (Fig. 1). The Hematite Creek, Katherine, and Little Dal groups in the Wernecke Mountains collectively comprise the Tonian Mackenzie Mountain Supergroup (MMS). In the Mackenzie Mountains, the MMS is capped by the Little Dal Group. The Tsezotene Formation, which overlies the basal Tabasco Formation in the Mackenzie Mountains, is inferred to be correlative with the Hematite Creek Group in the Wernecke Mountains (Fig. S2). Broadly equivalent strata of the Fifteenmile Group occur in the Proterozoic inliers in the Ogilvie Mountains to the west in Yukon (Fig. S2).

\section{Age constraints on the Hematite Creek Group and Dolores Creek fossils}

The minimum age of the MMS is provided by a U-Pb zircon Isotope Dilution-Thermal Ionization Mass Spectrometry (ID-TIMS) age of $775.10 \pm 0.54 \mathrm{Ma}$ on a diabase that crosscuts the MMS in the neighbouring Mackenzie Mountains (Milton et al., 2017). This diabase is considered part of the Gunbarrel magmatic event, which includes the Little Dal Basalt capping the MMS in the Mackenzie Mountains (Fig. S2). The base of the Mackenzie Mountain Supergroup is constrained to be younger than ca. 1000 Ma based on detrital muscovite Ar-Ar ages of $1033 \mathrm{Ma}$ from the lower Hematite Creek Group (Thorkelson, 2000) and detrital zircon U-Pb ages of ca. $1000 \mathrm{Ma}$ from presumed equivalent strata in the Hart River inlier to the west ((Rainbird et al., 1997); Fig. S2). The Re-Os isochron age of $896 \pm 45 \mathrm{Ma}$ (this study) was obtained on the Dolores Creek 
Formation approximately $6.7 \mathrm{~km}$ northwest of the fossil locality (Fig. S3). Though not precise, these ages are consistent with other ages on the MMS and equivalent strata across northwestern Canada that indicate an early Tonian age for the Hematite Creek Group (Fig. S2). Based on these collective dates and stratigraphic framework of the Hematite Creek Group, we infer an age of ca. 950-900 Ma for the Dolores Creek fossils.

\section{Depositional setting of the Dolores Creek fossils}

The Dolores Creek Formation characteristically comprises $\sim 300 \mathrm{~m}$ of interbedded grey to black shale and microbial carbonates. In the northern part of the outcrop belt in the Wernecke Mountains, the carbonates are mainly microbialaminite facies inferred to have been deposited in shallow-water lagoonal to peritidal environments. In the vicinity of the fossil locality, the Dolores Creek Formation increases abruptly in thickness to $\sim 1000 \mathrm{~m}$ (Figs. S4, S5, S6). Here, we have informally divided the Dolores Creek Formation into a lower and upper unit. The lower Dolores Creek Formation is $\sim 600 \mathrm{~m}$ thick and consists mainly of shale and siltstone with minor intraclast breccias and wackes interpreted to have been deposited as gravity flow debrites. The unit gradually coarsens upwards and includes a minor but increasing amount of carbonate, first in the form of debrite clasts, then as minor microbially laminated beds and blocks of stromatolites (olistoliths) and finally in-place stromatolite bioherms. The upper Dolores Creek Formation consists of shales and biostromes of columnar stromatolites, with the shales becoming increasingly organic-rich towards the top of the section, which corresponds stratigraphically to the location of the Re-Os age sample site.

The facies in the Dolores Creek Formation suggest an initially deepwater slope environment at this locality, with a proximal, prograding shelf margin to the north. Given the abrupt appearance of the lower Dolores Creek Formation here, we infer that the shelf margin represents a fault escarpment that formed in response to an extensional episode that initiated subsidence and formed the Hematite Creek Basin (Turner, 2011). Stromatolites on the shelf margin (Figs. S5, S6) shed debris as the shelf margin gradually prograded southward (in present coordinates) filling the deeper sub-basin.

The fossil interval occurs in gravity flow deposits above the fine-grained siliciclastic sediments and at the base of a shoaling upward cycle of shale to carbonate between 500 520 meters from the base of the measured section. Given that the first semi-continuous stromatolitic units occur only about 20 meters above the fossiliferous interval (Fig. S4, S6), by which point debrites also disappear, we infer that the fossils were deposited in an upper slope environment. It follows that both the fossils and other redeposited intraclastic debris were derived from the shelf margin. Hence, we conclude that the fossils record algae that inhabited the seafloor at the shelf edge, presumably between stromatolitic build-ups that rimmed the margin. Episodic gravity flow depositional events presumably ripped up benthic algae from the shelf margin, transporting them down slope where they were entombed: this rapid burial contributed porewater anoxia and fossilization under sulfate-reducing conditions.

Although, the lower Dolores Creek Formation lacks sedimentary structures that would provide unambiguous evidence for a marine setting for the fossils, the thickness of the 
fine-grained siliciclastic package ( $\sim 1$ kilometer) is hard to reconcile with a lacustrine depositonal setting. Further, the overlying Black Canyon Formation, which represents the continuation of the progradational high-stand systems tract spanning the Dolores Creek Formation, consists mainly of meter-scale shale-carbonate cycles deposited in a shallow, restricted, but tidally influence environment. Evidence of tidal currents is found in the occurrence of bidirectional current indicators (ripples, cross-bedding, and imbricated tabular clasts), abundant reactivation surfaces, and draping of bedforms by fine-grained dololutite (Fig. S7A). Cauliflower structure (Fig. S7B), interpreted to record chert replacing enterolithic anhydrite, is common throughout the Black Canyon Formation and into the lower Tarn Lake Formation. These anhydrite nodules provide evidence for the availability of sulphate, which was presumably seawater and contributed to fossil preservation. Microbialaminite facies characteristic of inter- to supratidal environments are also abundant in the Black Canyon Formation (Fig. S7C; (Turner, 2011)). In summary, we suggest that the Dolores Creek biota likely inhabited mid-shelf to marginal marine setting in the Hematite Creek Basin.

\section{Algal Fossil Record}

Marine fossils interpreted as algae are found throughout the Proterozoic. For example, the organic-walled microfossils Dictyosphaera, Shuiyousphaeridium, and

Gigantosphaeridium from the Paleoproterozoic Ruyang Group in North China have been interpreted as microscopic and phytoplanktonic green algae (Agić et al., 2015, 2017).

Similarly, eosolenid tubular fossils with a sub-millimeter width and transverse septa from late Mesoproterozoic strata in Siberia (German and Podkovyrov, 2009) and early Neoproterozoic strata in North China (Li et al., 2020), as well as, annulated and millimeter-sized tubular fossils such as Proteroarenicola, Pararenicola, Sinotubulites, and Parmia from early Neoproterozoic rocks in North China (Dong et al., 2008; Li et al., 2020), India (Sharma and Shukla, 2012), and Russia (Gnilovskaya, 1998), may also be green algae, although strong cases for the affinity of these taxa have not been formally made. Enigmatic, long-ranging macroscopic fossils such as Chuaria (Tang et al., 2017) and Grypania date back to ca. $1870 \mathrm{Ma}$ (Han and Runnegar, 1992) and have been previously interpreted as algae (Walter et al., 1976), but this interpretation remains contentious (Sharma and Shukla, 2009). The ca. 1560 Ma Gaoyuzhuang biota of North China include carbonaceous compressions up to $30 \mathrm{~cm}$ in length that have also been interpreted as algae (Zhu et al., 2016), but these carbonaceous compressions lack cellular preservation, and it is uncertain which algal group they might represent.

\section{The late Mesoproterozoic-Tonian fossil record in northern Canada}

Late Mesoproterozoic to Neoproterozoic strata of northern Canada hosts a diverse fossil assemblage that includes Ediacaran-type impressions (Narbonne and Hofmann, 1987; Narbonne et al., 1994, 2014), the Rusty assemblage (Butterfield, 2005b), the Wynniatt assemblage (Butterfield, 2005b, 2005a), and red algal microfossils (Bangiomorpha; (Butterfield, 2000)). Recent discoveries of Tonian fossils including vase-shaped microfossils (Strauss et al., 2014; Cohen et al., 2017a) and scale microfossils (Cohen and Knoll, 2012; Cohen et al., 2017b) have invigorated the continued search for early life in older units in the Arctic resulting in new reports of fungal microfossils (Ourasphaira giraldae, (Loron et al., 2019)), evidence for eukaryovory (Loron et al., 2018) and green 
algal macrofossils (this study) from ca. 100-900 Ma. The appearance of Bangiomorpha (ca. 1050, (Butterfield, 2000; Gibson et al., 2018), Ourasphaira giraldae $(<1,013 \pm 25$ to $>892 \pm 13 \mathrm{Ma}$; (Loron et al., 2019)), and the Dolores Creek green algal fossils reported in this study provide evidence of a more complex ecosystem during the Tonian Period than previously documented.

\section{Other Tonian algal fossils}

The fossil record of early algae is sparse and characterized by great uncertainty.

Proterocladus from the ca. 790 Ma Svanbergfjellet Formation in Spitsbergen and ca. 1000 Ma Nanfen Fromation in North China has been interpreted as a siphonocladous green alga (Butterfield et al., 1994; Tang et al., 2020). The ca. 1000 Ma fossil Palaeovaucheria clavata from the $\sim 1000$ Ma Lakhanda Group of southeastern Siberia has been interpreted as a putative xanthophyte algae (Hermann, 1990). Bangiomorpha pubescens from the ca. $1050 \mathrm{Ga}$ Angmaat and Hunting formations in northwestern Canada (Butterfield, 2000; Gibson et al., 2018) is the oldest taxonomically-resolved algal fossil and has been interpreted as a bangiophyte red alga. Other multicellular fossils from the Tonian strata of Victoria Island (Canada; ca. $850 \mathrm{Ma}$ ) and Svalbard (ca. $820 \mathrm{Ma}$ ) have been interpreted as stem group eukaryotes, but these problematic fossils are much smaller, typically $\sim 50 \mu \mathrm{m}$ wide and several hundred micrometers in length (Butterfield, 2015).

Early Neoproterozoic macroalgal assemblages are typically dominated by simple forms (Xiao and Dong, 2006; Xiao and Tang, 2018). Algal thalli have previously been reported with well-differentiated stipe and holdfast structures in Longfengshania from the Tonian Little Dal Group which caps the MMS in northwestern Canada (Hofmann, 1985).

Sinosabellidites and pararenicolids from the Liulaobei Formation in North China (Dong et al., 2008) also exhibits a cylindrical thallus ornamented with transverse annulations and bear a distinct holdfast structures. These morphological innovations highlight the growing competition for resources and/or space between species (Wang et al., 2015). 


\section{SUPPLEMENTAL FIGURES AND TABLES}
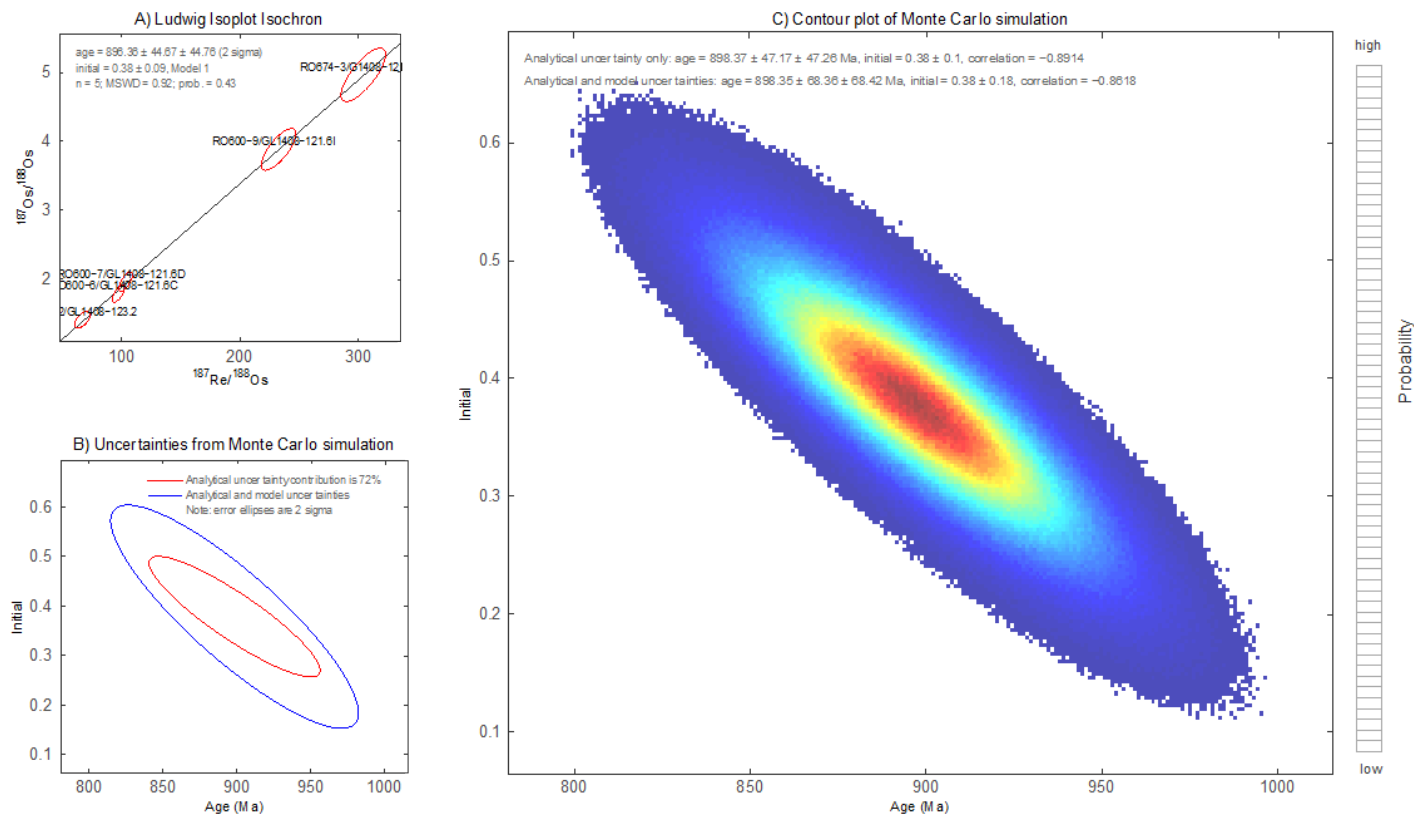

Fig. S1. Re-Os isotope data analysis for the Dolores Creek Formation using the benchmark “'Isoplot” algorithm (A) and Monte Carlo simulation (B, C) (Li et al., 2019. (A) Regression of Re-Os data yielded a Model 1 Re-Os isochron age of $896 \pm 45 \mathrm{Ma}(2 \sigma$, $n=5$, mean square of weighted deviates $[\mathrm{MSWD}]=0.92$; uncertainty with and without the decay constant uncertainty is 44.67 and $44.76 \mathrm{Ma}$, respectively) with an initial ${ }^{187} \mathrm{Os} /{ }^{188}$ Os composition $\left(\mathrm{Os}_{\mathrm{i}}\right)$ of $0.38 \pm 0.09$. (B) Uncertainties from the Monte Carlo simulation with analytical uncertainty contribution shown in red with the analytical and model uncertainties shown in blue (error ellipses are 2 sigma). (C) Contour plot of Monte Carlo simulation yielding essentially an identical age to the benchmark Isoplot algorithm ( $898 \pm 68 \mathrm{Ma}$ including both analytical and model age uncertainties). Elemental abundances and isotopic compositions are presented in Data S1. 


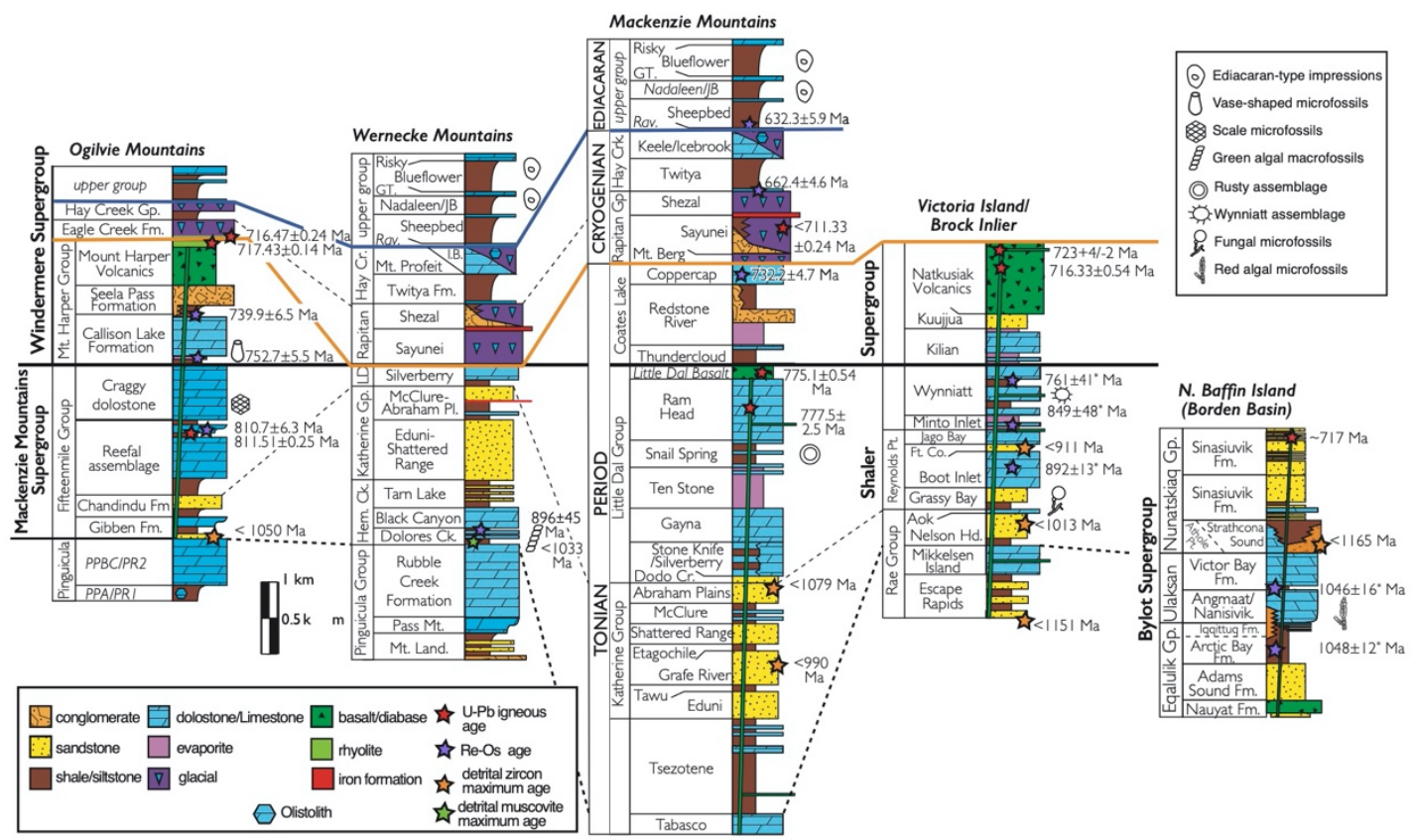

Fig. S2. Regional correlations of the Proterozoic stratigraphy in NW Canada, showing available radiometric age constraints and key fossil occurrences. Thick orange correlation line is the sub-Cryogenian unconformity and thick blue line marks the CryogenianEdiacaran boundary. Gp-Group; Fm-Formation; FMG-Fifteenmile Group; Chan.Chandindu Formation; Ck.-Creek; Hem. Ck.-Hematite Creek Group; LD-Little Dal Group; Rav.- Ravensthroat formation; JB-June Beds; GT.-Gametrail Formation; Mt.Mount; conglom.- conglomerate; Ft. Co.-Fort Collinson Formation; Pt.-Point; Hd.Head. Geochronology from (Jefferson and Parrish, 1989; Thorkelson, 2000; Macdonald et al., 2010; Van Acken et al., 2013; Strauss et al., 2014; Rooney et al., 2015; Baldwin et al., 2016; Milton et al., 2017; Gibson et al., 2018) this paper. All geochronologic age uncertainties are $2 \sigma$. Re-Os age uncertainties also include uncertainty in the ${ }^{187}$ Re decay constant $(\lambda)$ except when not reported by original authors (denoted as $*$ ). Fossils include Ediacaran-type impressions (Narbonne and Hofmann, 1987; Narbonne et al., 1994, 2014), vase-shaped microfossils (Strauss et al., 2014; Cohen et al., 2017a), scale microfossils (Cohen and Knoll, 2012; Cohen et al., 2017b), green algal macrofossils (this paper), Rusty assemblage (58), Wynniatt assemblage (Butterfield, 2005b, 2005a), fungal microfossils (Loron et al., 2019), and red algal microfossils (Butterfield and Chandler, 1992; Butterfield, 2000). 


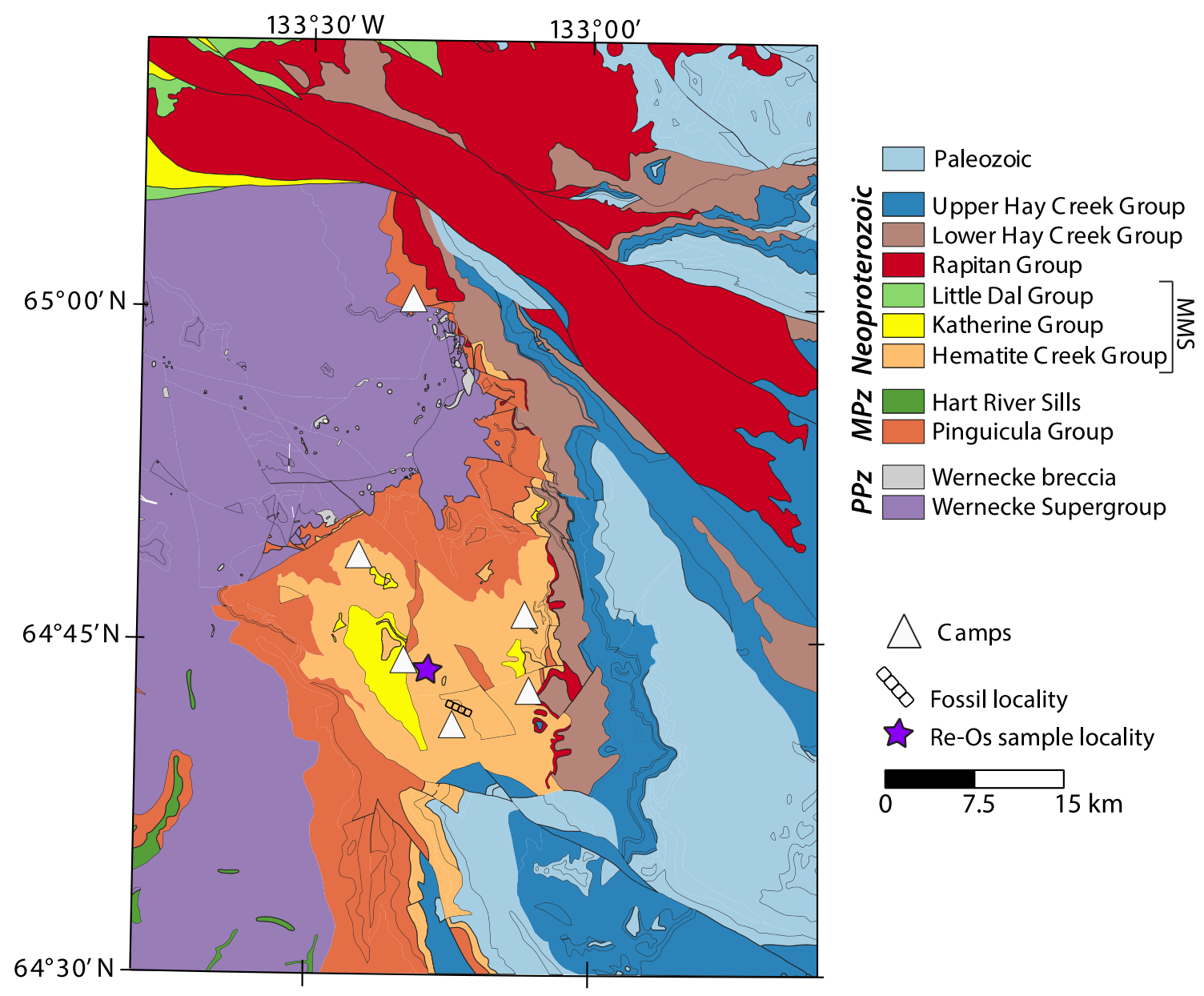

Fig. S3. Geological map of the main outcrop belt of the Tonian Mackenzie Mountain Supergroup (MMS) in the Wernecke Mountains, showing location of the fossil and ReOs sample localities. Map is modified from the Yukon Geological Survey Bedrock Geology Dataset (Yukon Geologic Survey, 2018). PPz-Paleoproterozoic; MPzMesoproterozoic. 

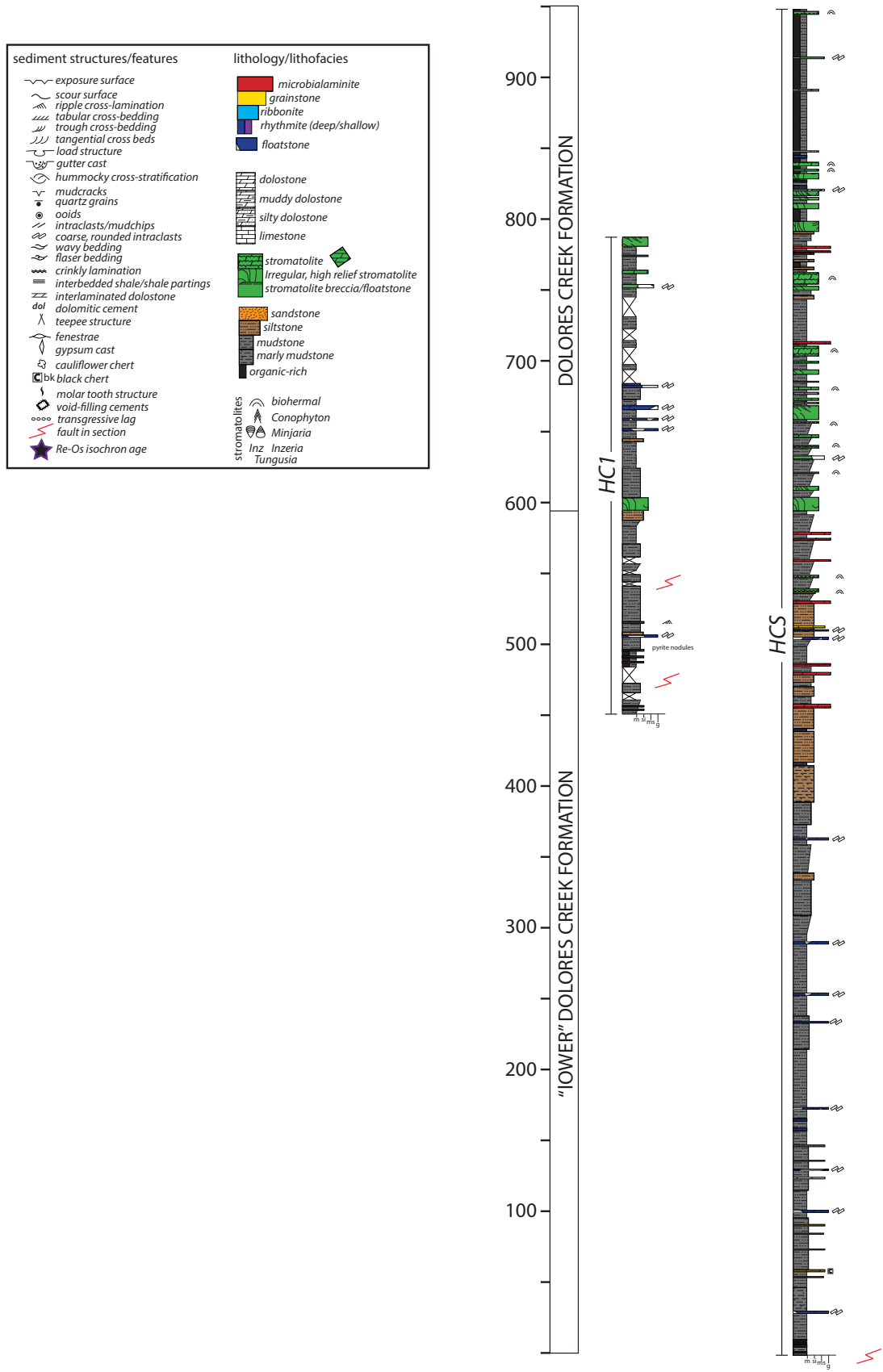

Fig. S4. Stratigraphic logs of the section of the Dolores Creek Formation containing the fossils (HCS $=$ Hematite Creek Section), and a partial parallel section (HC1), which lacked fossils. 


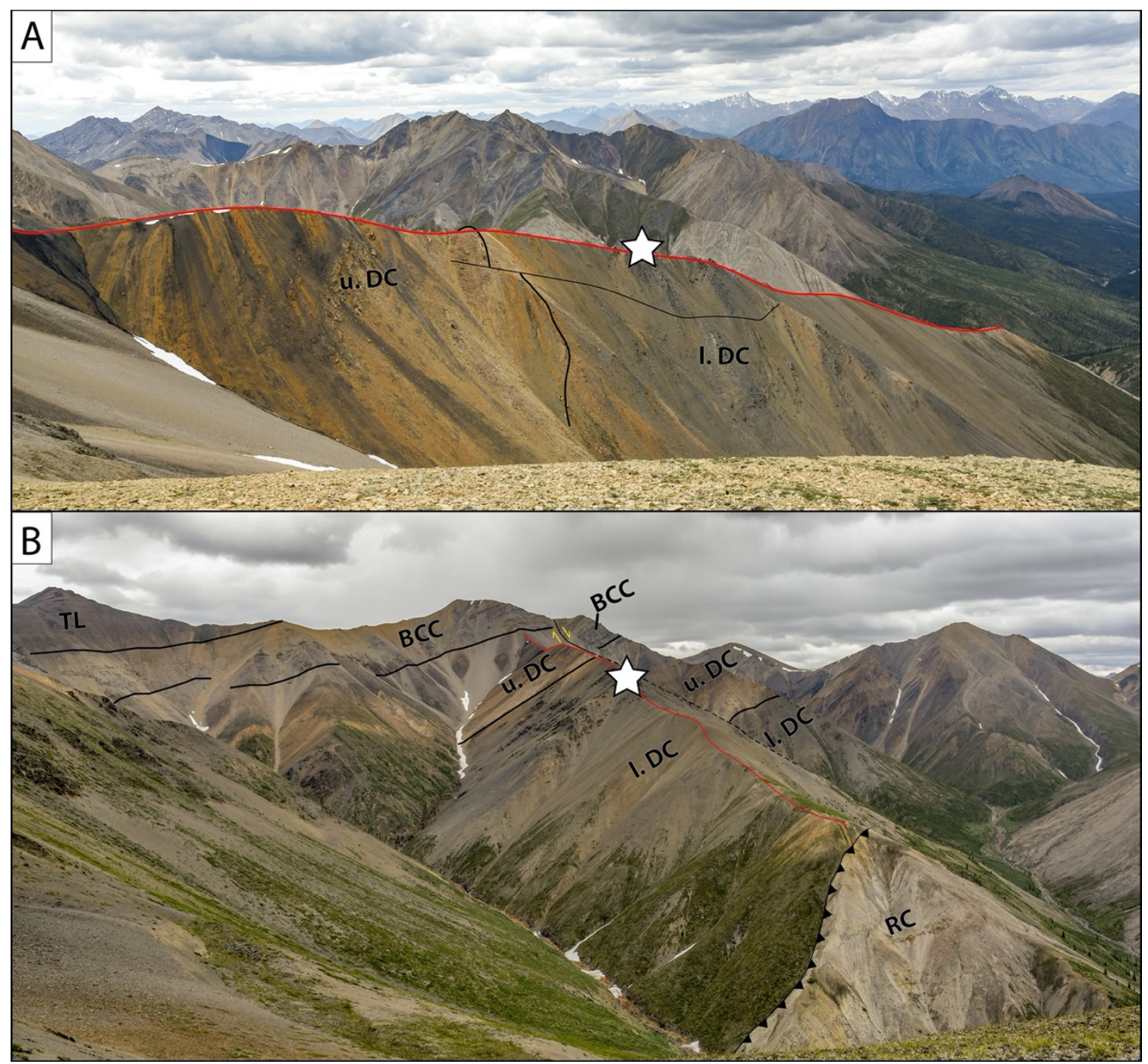

Fig. S5. Two views of the ridgeline near Hematite Creek where the Dolores Creek fossils occur (white star; N64ㄴ $41.2^{\prime} \mathrm{N}, 133^{\circ} 13.3^{\prime} \mathrm{W}$ ). Red line shows stratigraphic section HCS. $\mathrm{RC}=$ Rubble Creek Formation (Pinguicula Group); 1. DC = "lower" Dolores Creek Formation; u. DC = "upper" Dolores Creek Formation; BCC = Black Canyon Creek Formation; $\mathrm{TL}=$ Tarn Lake Formation. Lower resolution image used for submission. 


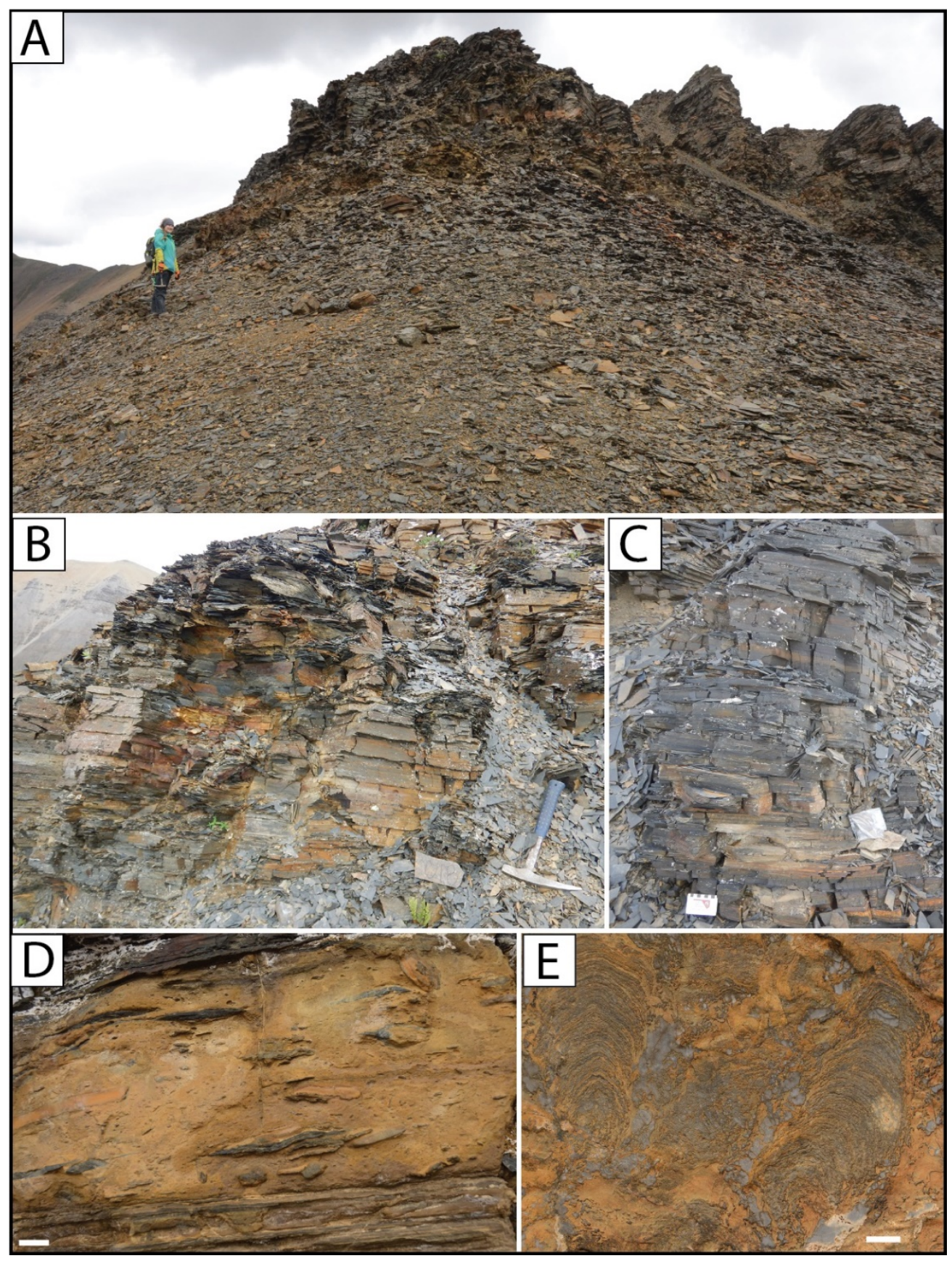

Fig. S6. Field photos showing the Hematite Creek Section fossil locality (A) and sedimentary facies (B-E). B and C show the dominantly silty shale facies in which fossils occur. (D) Debrite bed with tabular intraclasts within silty shales. (E) Columnar stromatolites within a bioherm above the fossil locality. Layers in columns and cements between columns consist of gray limestone outlined by ferruginous orange dolostone, which is a characteristic style of preservation of stromatolites encases in shales within the Dolores Creek Formation. Hammer in (D) is $28 \mathrm{~cm}$ in length. Increments on ruler in (C) are $1 \mathrm{~cm}$. Scale bars in (D) and (E) are $20 \mathrm{~mm}$ wide. Lower resolution image used for submission. 


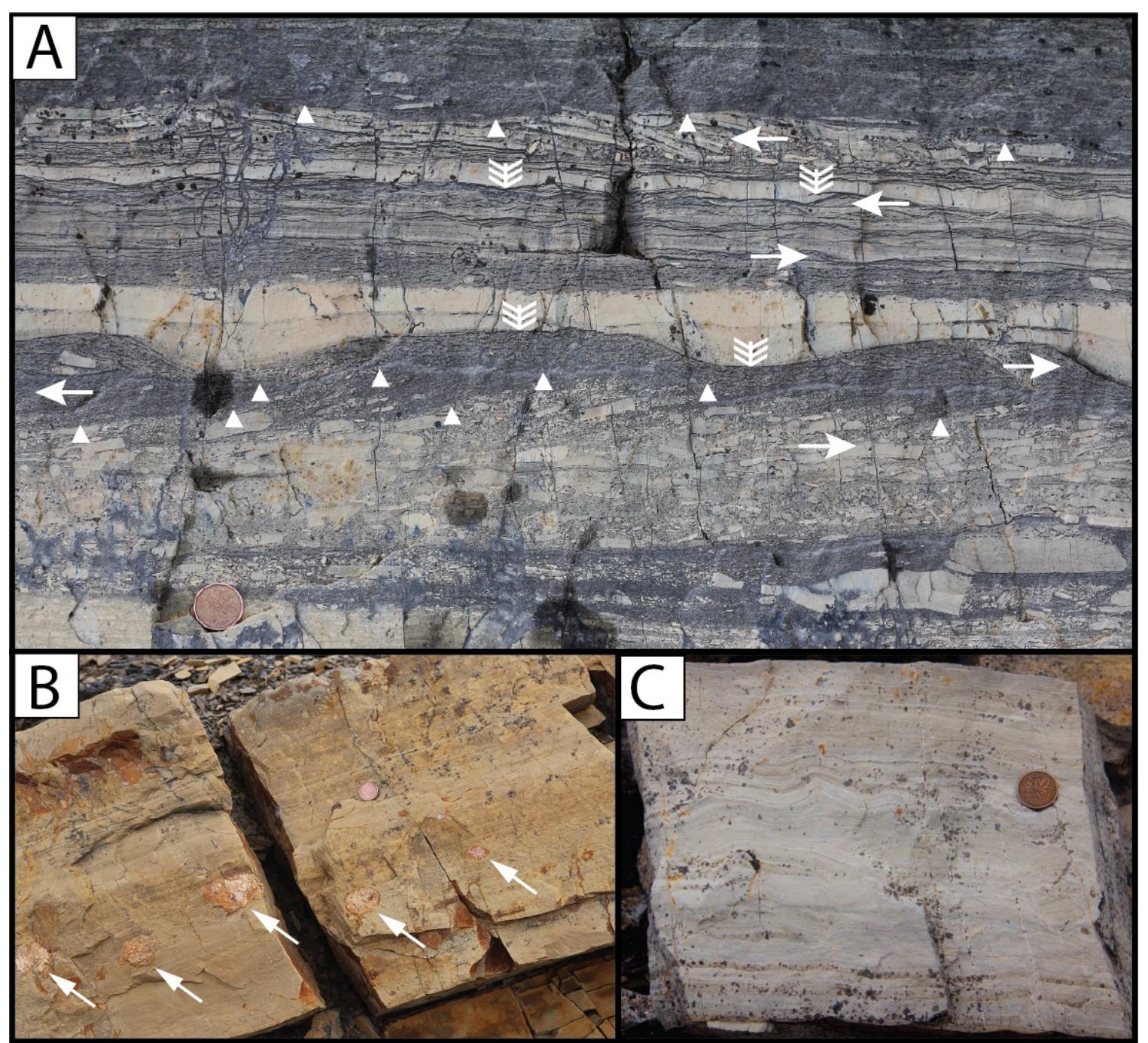

Fig. S7. Characteristic shallow-water carbonate facies in the Black Canyon Creek Formation, which directly overlies the Dolores Creek Formation. (A) Mixed grainstones, intraclastic breccia, and dololutite facies showing abundant evidence for tidal activity. Horizontal arrows indicate current directions from cross-bedding, ripple cross-lamination, and imbricated tabular intraclasts. Arrowheads show tidal reactivation surfaces. Arrow feather symbol shows bedform surfaces draped by fine-grained sediment (dololutite) deposited from slack water. This facies is also the source of the abundant intraclasts in this photograph, which were ripped up and reworked by tidal currents. (B) Cauliflower chert nodules (outlined by orange lichen, which prefers silica over carbonate), interpreted to be replaced anhydrite nodules. (C) Characteristic 'microbialaminite' facies in the Black Canyon Creek Formation, interpreted to record microbially influenced deposition in intertidal to supratidal environments. Lower resolution image used for submission. 


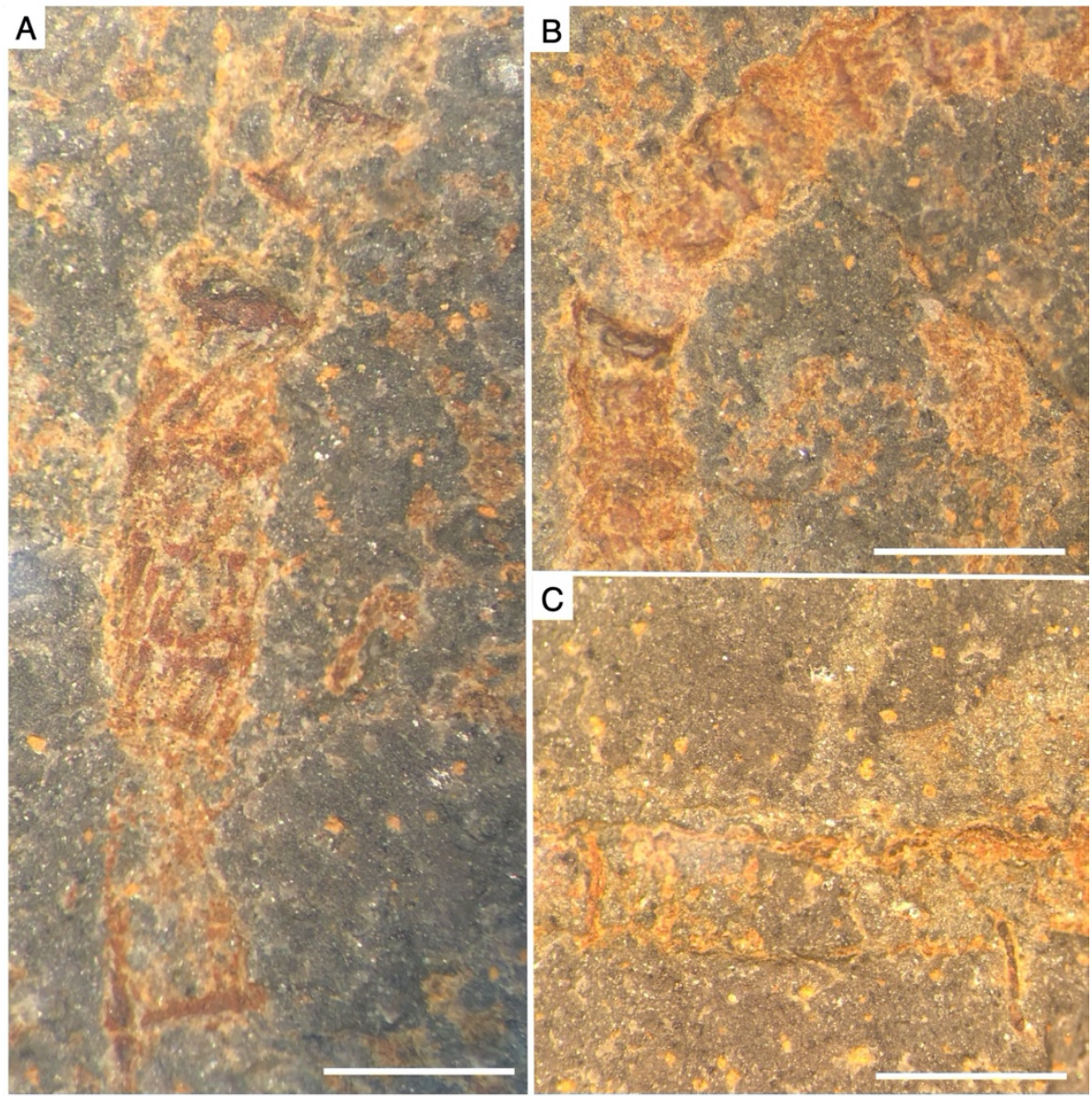

Fig. S8. Dolores Creek macrofossils showing three-dimensional preservation. (A-B) Specimens with longitudinal striations. (C) Smaller macroalga overlies large specimen. All specimens from ROMIP66170. Scale bars $=1 \mathrm{~mm}$. Lower resolution image used for submission. 


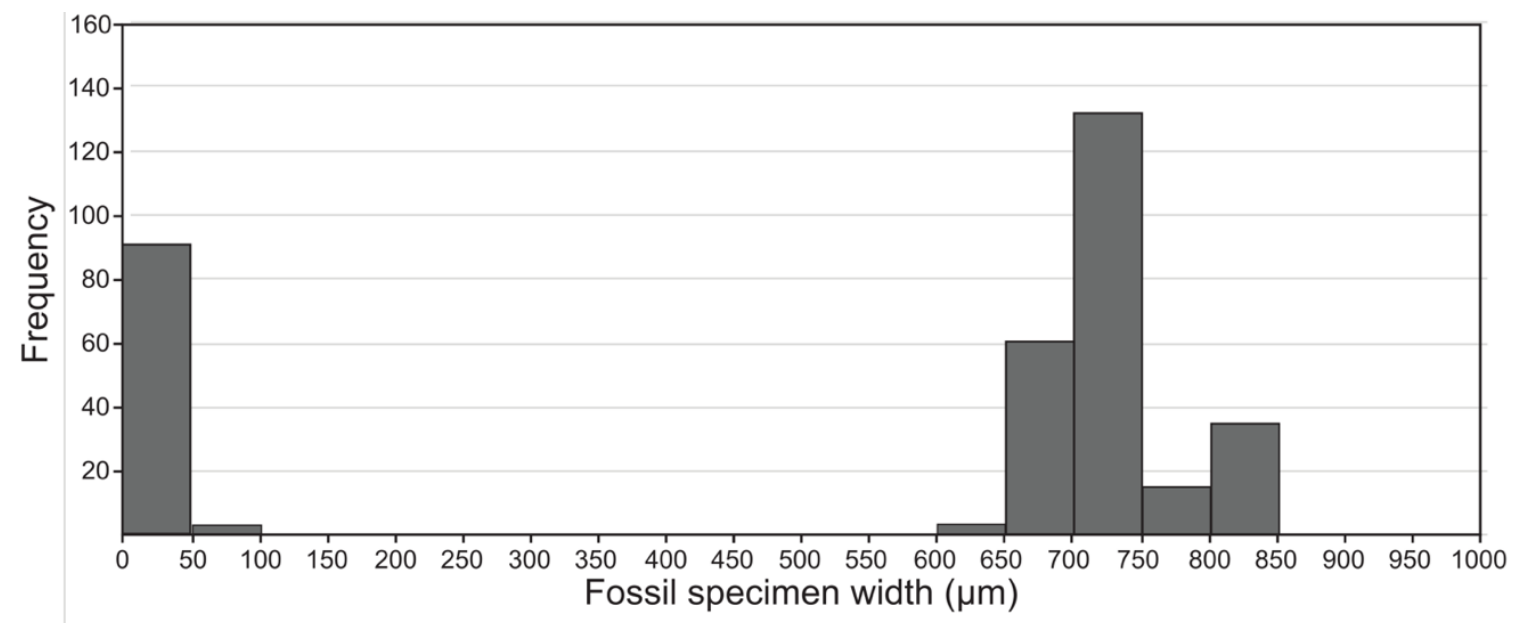

Fig. S9. Histogram of specimen widths showing two distinct size classes: smaller specimens $(30-50 \mu \mathrm{m})$ and larger specimens $(600-800 \mu \mathrm{m})$. 


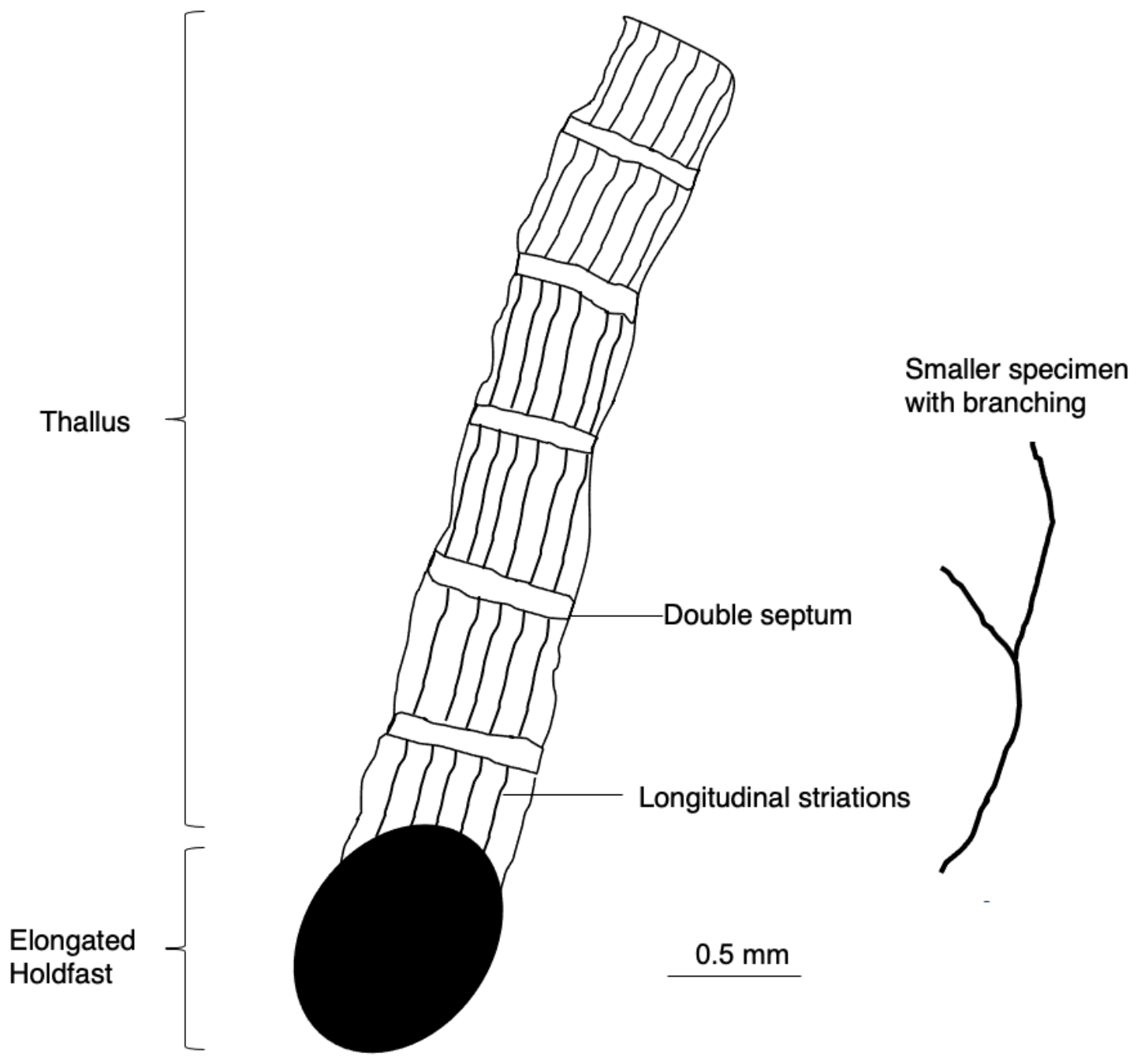

Fig. S10. Schematic diagram of a macroalgal specimen from the larger size class, illustrating double septa, an ellipsoidal to globose holdfast, and longitudinal striations. Smaller size class specimen with branching is shown for size comparison. 

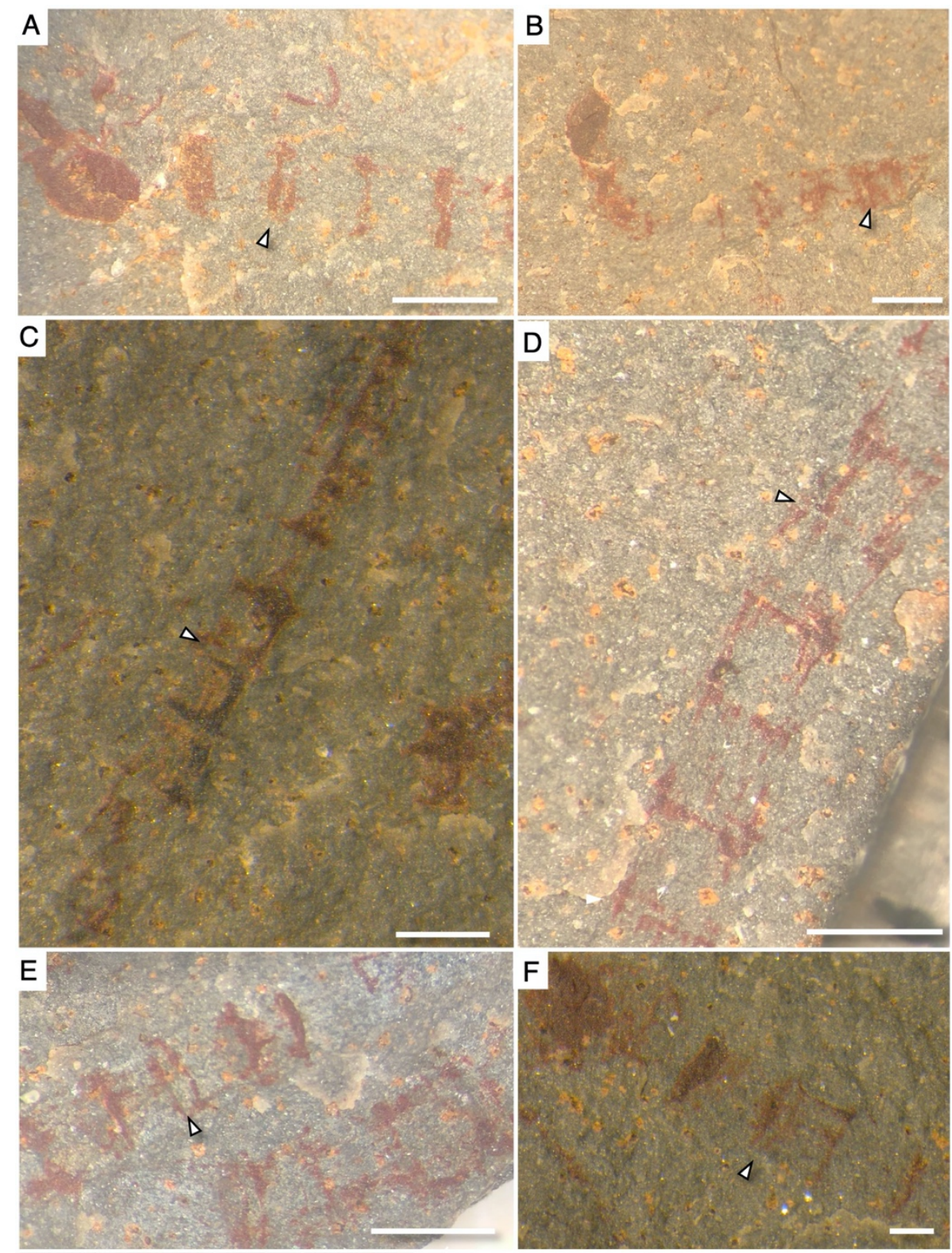

Fig. S11. Dolores Creek macrofossils of the larger size class, highlighting the presence of double septa. (A-B) Double septa highlighted with white arrows. (C-F) Specimens have double septa and contain longitudinal striations. Specimens are from ROMIP66167 with the exception of B and E from ROMIP66169. Scale bars $=1 \mathrm{~mm}$. Lower resolution image used for submission. 

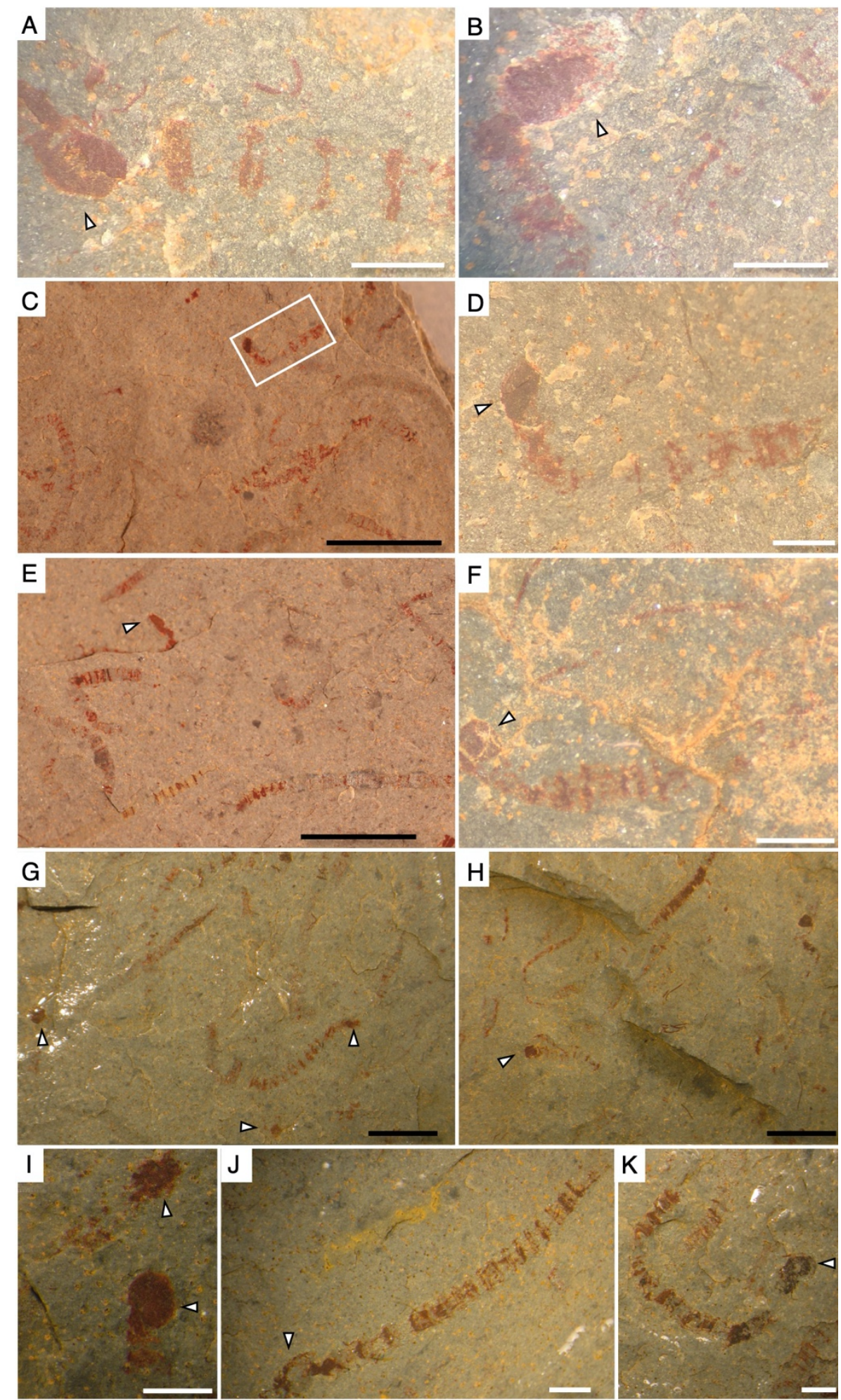

Fig. S12. Dolores Creek macrofossils (larger size class) with putative holdfasts (white arrows). Specimens are from ROMIP66167 with the exception of C-D from ROMIP66169. White scale bars $=1 \mathrm{~mm}$. Black scale bars $=5 \mathrm{~mm}$. Lower resolution image used for submission. 

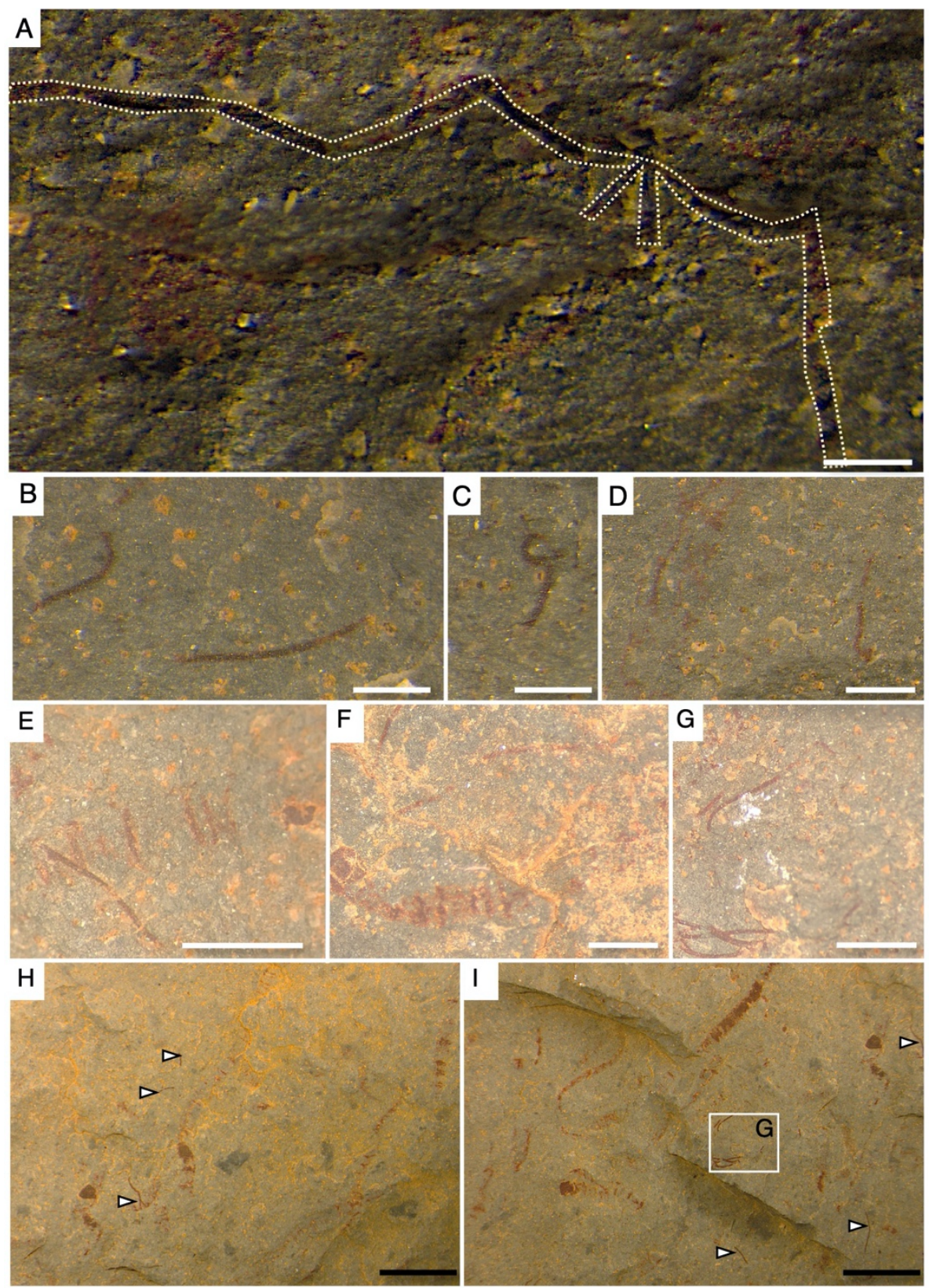

Fig. S13. Macrofossils from the smaller size class. (A) Branching specimen highlighted with dotted outline (B) Smaller specimens (C) Deformed smaller specimen (D) Smaller adjacent to large specimen (E) Smaller overlapping larger specimen (F) Specimens can be comparable in length to the larger macroalgae $(\mathrm{G})$ Overlapping specimens $(\mathrm{H})$ Distribution of several specimens including a small branching organism (I) Location of $G$ on the sample showing the distribution of fossils. All specimens from ROMIP66167. White scale bars $=1 \mathrm{~mm}$, Black scale bars $=5 \mathrm{~mm}$. Lower resolution image used for submission. 


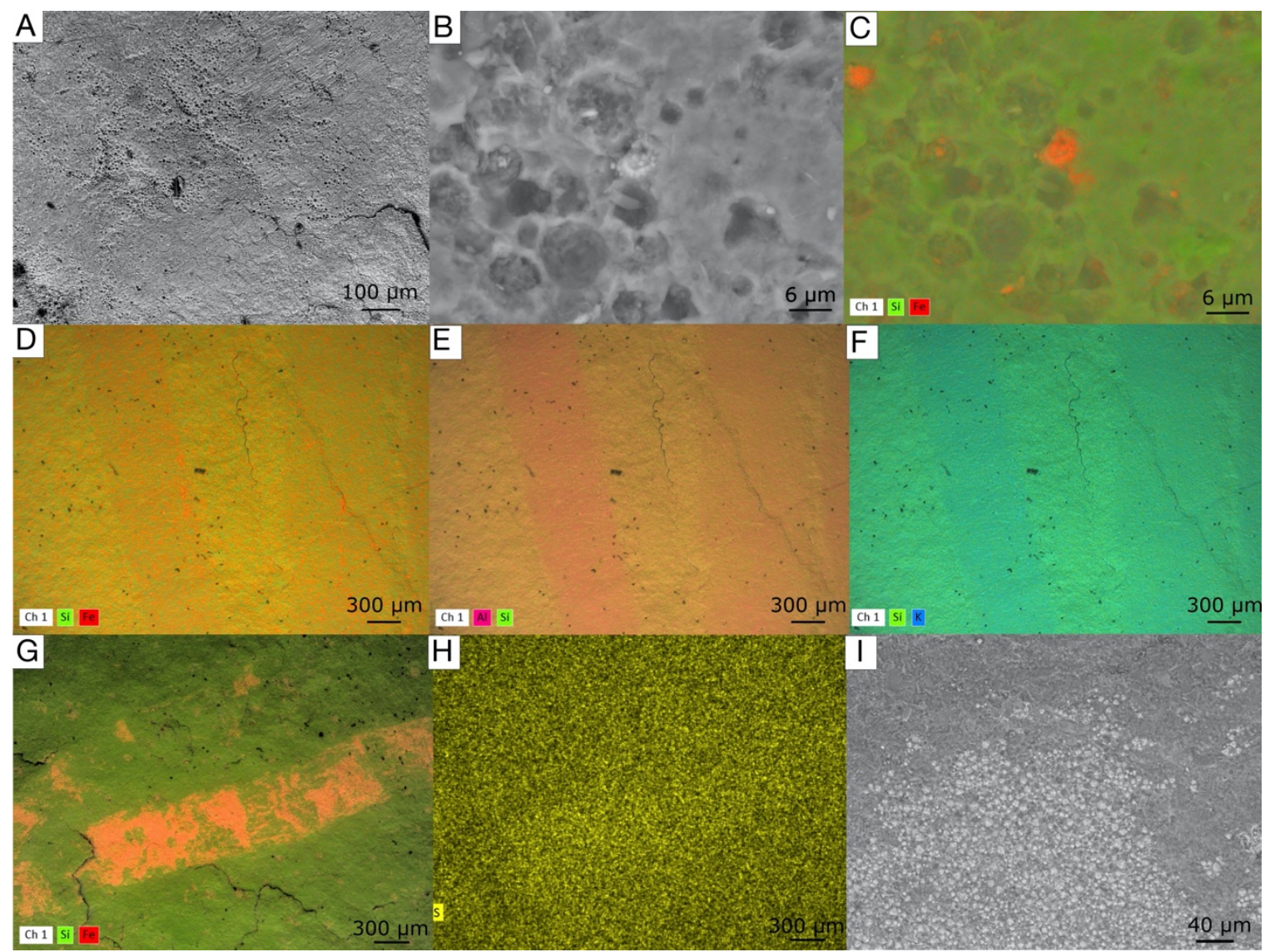

Fig. S14. Variable preservation textures within the larger size class macrofossils of the Dolores Creek Formation. (A) BSE SEM image showing platy, linear structures (probably clays) and pits (probably molds of pyrite framboids) on macrofossils. (B) Enlarged image of pits and (C) EDS elemental map showing that the pits contain iron. (D-F) EDS elemental maps showing platy features have an increase in the relative enrichment in iron, aluminium, and potassium supporting a clay origin. (G) EDS elemental map showing specimen with a relative enrichment in iron. (H) EDS elemental map showing same specimen as $G$ with a limited relative enrichment in sulfur. (I) BSE SEM image showing iron oxide pseudomorphs, probably representing weathering product of pyrite framboids. A-F are sample ROMIP66163, G-I are sample ROMIP66165. Lower resolution image used for submission. 


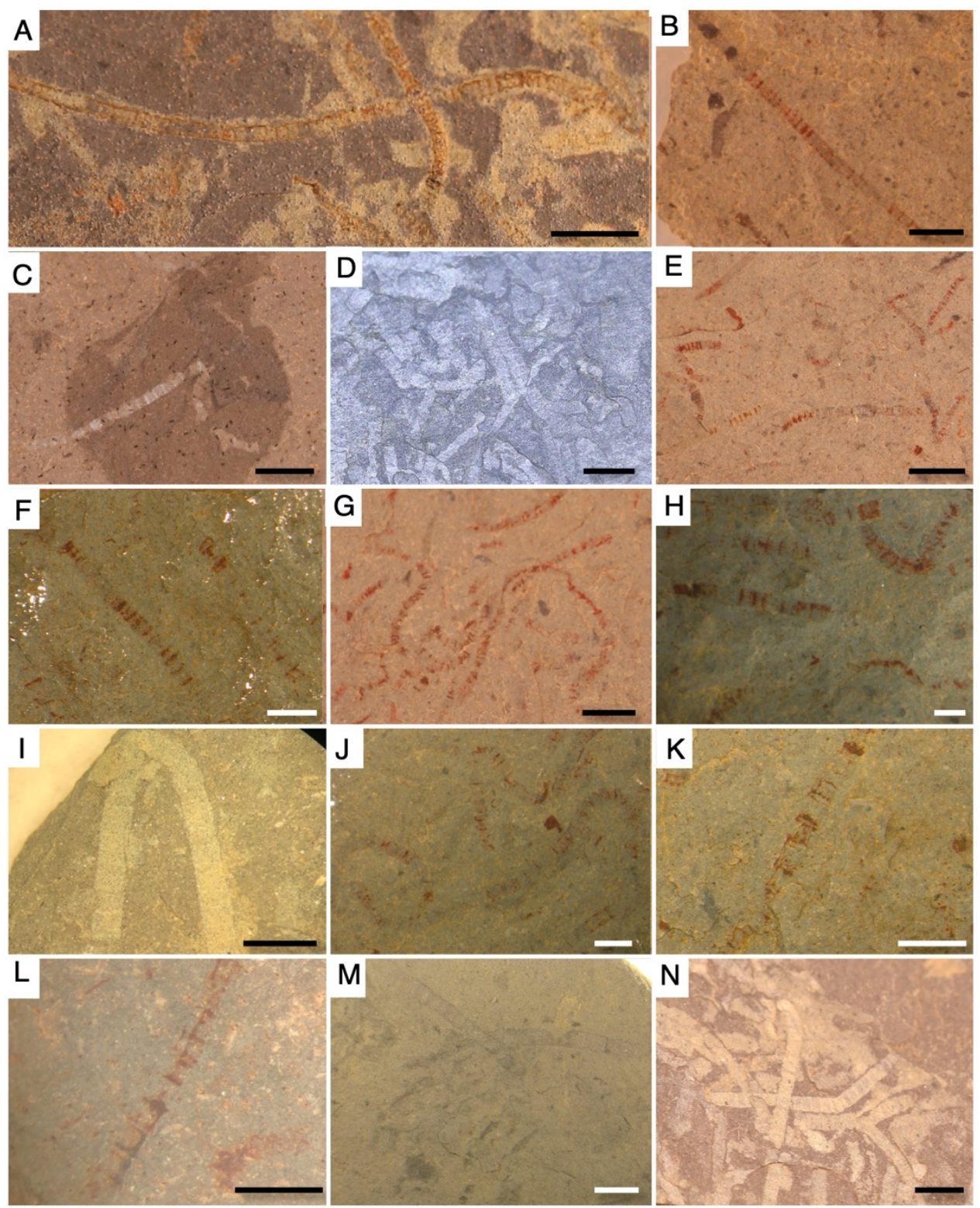

Fig. S15. Additional macroalgal specimens of the larger size class, demonstrating the abundance and preservation of fossils. Sample Numbers: (A) ROMIP66170. (B) ROMIP66169. (C) ROMIP66162. (D) ROMIP66160. (E) ROMIP66167. (F) ROMIP66168. (G) ROMIP66167. (H) ROMIP66167. (I) ROMIP66161. (J) ROMIP66167. (K) ROMIP66169. (L) ROMIP66167. (M) ROMIP66166. (N) ROMIP66164. White scale bars $=1 \mathrm{~mm}$, Black scale bars $=3 \mathrm{~mm}$. Lower resolution image used for submission. 
Movie S1 (separate file). X-ray microtomography of Dolores Creek macroalgal specimen from sample ROMIP66170 from the larger size class, highlighting the threedimensional preservation of fossils.

Dataset S1. Synopsis of the Re-Os data for sample suites GL1408.

\begin{tabular}{|c|c|c|c|c|c|c|c|c|c|c|c|c|c|c|c|c|}
\hline Batch/Sample & $\operatorname{Re}(p p b)$ & \pm & Os (ppt) & \pm & ${ }^{192}$ Os (ppt) & \pm & ${ }^{187} \mathrm{Re} /{ }^{188}$ Os & \pm & ${ }^{187} \mathrm{Os} /{ }^{188}$ Os & \pm & rho & $\begin{array}{c}\% \text { Re } \\
\text { Blank } \\
\end{array}$ & $\begin{array}{c}\%{ }^{187} \text { Os } \\
\text { Blank } \\
\end{array}$ & $\begin{array}{c}\%{ }^{188} \text { Os } \\
\text { Blank } \\
\end{array}$ & $\begin{array}{c}\text { Os } \mathrm{s}_{\mathrm{i}} @ \\
896 \mathrm{myr}\end{array}$ & \pm \\
\hline RO600-6_GL1408-121.6C & 0.501 & 0.006 & 30.1 & 0.7 & 10.2 & 0.4 & 97.6 & 4.3 & 1.80 & 0.10 & 0.692 & 2.0 & 0.04 & 0.2 & 0.33 & 0.10 \\
\hline RO600-7_GL1408-121.6D & 0.461 & 0.006 & 26.6 & 0.6 & 8.8 & 0.4 & 103.6 & 4.6 & 1.97 & 0.11 & 0.692 & 2.2 & 0.04 & 0.3 & 0.41 & 0.11 \\
\hline RO674-3_G1408-121.6F & 0.798 & 0.008 & 20.6 & 0.6 & 5.2 & 0.3 & 304.0 & 15.3 & 4.97 & 0.32 & 0.761 & 3.0 & 0.04 & 0.7 & 0.39 & 0.32 \\
\hline RO600-9_GL1408-121.6I & 0.481 & 0.006 & 14.8 & 0.4 & 4.1 & 0.2 & 232.6 & 11.9 & 3.89 & 0.25 & 0.753 & 2.1 & 0.04 & 0.6 & 0.39 & 0.25 \\
\hline RO601-2_GL1408-123.2 & 0.138 & 0.008 & 11.6 & 0.3 & 4.1 & 0.2 & 67.0 & 5.2 & 1.41 & 0.10 & 0.565 & 9.1 & 0.20 & 0.70 & 0.41 & 0.10 \\
\hline
\end{tabular}

Re blank $=10 \pm 3 \mathrm{pg}$, Os blank $=0.06 \pm 0.15$, with $\mathrm{a}^{187} \mathrm{Os} /{ }^{188} \mathrm{Os}=0.25 \pm 0.05(\mathrm{~N}=3)$

rho = associated error correlation (Ludwig, 1980)

Osi $=$ intial ${ }^{187} \mathrm{Os} /{ }^{188} \mathrm{Os}$ composition calculated using the decay constant of ${ }^{187} \mathrm{Re}$ and the Re-Os isochron age of $896 \mathrm{Ma}$.

Dataset S2 (separate file). Fossil Measurement Data

\section{SUPPLAEMENTAL REFERENCES}

Agić, H., Moczydłowska, M., and Yin, L.M., 2015, Affinity, life cycle, and intracellular complexity of organic-walled microfossils from the Mesoproterozoic of Shanxi, China: Journal of Paleontology, v. 89, p. 28-50, doi:10.1017/jpa.2014.4.

Agić, H., Moczydłowska, M., and Yin, L., 2017, Diversity of organic-walled microfossils from the early Mesoproterozoic Ruyang Group, North China Craton - A window into the early eukaryote evolution: Precambrian Research, v. 297, p. 101-130, doi:10.1016/j.precamres.2017.04.042.

Baldwin, G.J., Turner, E.C., and Kamber, B.S., 2016, Tectonic controls on distribution and stratigraphy of the Cryogenian Rapitan iron formation, northwestern Canada: Precambrian Research, v. 278, p. 303-322, doi:10.1016/j.precamres.2016.03.014.

Butterfield, N.J., 2000, Bangiomorpha pubescens n. gen., n. sp.: implications for the evolution of sex, multicellularity, and the Mesoproterozoic/Neoproterozoic radiation of eukaryotes : Paleobiology, v. 26, p. 386-404, doi:10.1666/00948373(2000)026<0386:bpngns $>2.0 . c 0 ; 2$.

Butterfield, N.J., 2005a, Probable Proterozoic Fungi: Paleobiology, v. 55, p. 831-856, doi:10.1017/S0018246X12000325.

Butterfield, N.J., 2005b, Reconstructing a complex early Neoproterozoic eukaryote, Wynniatt Formation, arctic Canada: Lethaia, v. 38, p. 155-169, doi:10.1080/00241160510013231.

Butterfield, N.J., 2015, The neoproterozoic: Current Biology, v. 25, p. R859-R863, doi:10.1016/j.cub.2015.07.021.

Butterfield, N.J., and Chandler, F.W., 1992, Palaeoenvironmental distribution of Proterozoic microfossils, with an example from the Agu Bay Formation, Baffin Island: Palaeontology, v. 35, p. 943-957. 
Butterfield, N.J., Knoll, A.H., and Swett, K., 1994, Paleobiology of the Neoproterozoic Svanbergfjellet Formation, Spitsbergen: Fossils \& Strata, v. 34, p. 1-84.

Cohen, P.A., Irvine, S.W., and Strauss, J. V., 2017a, Vase-shaped microfossils from the Tonian Callison Lake Formation of Yukon, Canada: taxonomy, taphonomy and stratigraphic palaeobiology: Palaeontology, v. 60, p. 683-701, doi:10.1111/pala.12315.

Cohen, P.A., and Knoll, A.H., 2012, Scale microfossils from the mid-Neoproterozoic Fifteenmile Group, Yukon Territory: Journal of Paleontology, v. 86, p. 775-800, doi:10.1666/11-138.1.

Cohen, P.A., Strauss, J. V., Rooney, A.D., Sharma, M., and Tosca, N., 2017b, Controlled hydroxyapatite biomineralization in an $\sim 810$ million-year-old unicellular eukaryote: Science Advances, v. 3, p. 1-9, doi:10.1126/sciadv.1700095.

Cumming, V.M., Poulton, S.W., Rooney, A.D., and Selby, D., 2013, Anoxia in the terrestrial environment during the late Mesoproterozoic: Geology, v. 41, p. 583-586, doi:10.1130/G34299.1.

Dong, L., Xiao, S., Shen, B., Yuan, X., Yan, X., and Peng, Y., 2008, Restudy of the worm-like carbonaceous compression fossils Protoarenicola, Pararenicola, and Sinosabellidites from early Neoproterozoic successions in North China: Palaeogeography, Palaeoclimatology, Palaeoecology, v. 258, p. 138-161, doi:10.1016/j.palaeo.2007.05.019.

Du Vivier, A.D.C., Selby, D., Sageman, B.B., Jarvis, I., Gröcke, D.R., and Voigt, S., 2014, Marine 1870s/188Os isotope stratigraphy reveals the interaction of volcanism and ocean circulation during Oceanic Anoxic Event 2: Earth and Planetary Science Letters, v. 389, p. 23-33, doi:10.1016/j.epsl.2013.12.024.

German, T.N., and Podkovyrov, V.N., 2009, New insights into the nature of the Late Riphean Eosolenides: Precambrian Research, v. 173, p. 154-162, doi:10.1016/j.precamres.2009.03.018.

Gibson, T.M. et al., 2018, Precise age of Bangiomorpha pubescens dates the origin of eukaryotic photosynthesis: Geology, v. 46, p. 135-138, doi:10.1130/G39829.1.

Gnilovskaya, M.B., 1998, The ancient annelidomorphs from the upper Riphean of Timan.: Doklady Akademii Nauk, v. 359, p. 369-372.

Han, T., and Runnegar, B., 1992, Megascopic eukaryotic algae from the 2.1-billion-yearold Negaunee iron-formation, Michigan: Science, v. 257, p. 232-235.

Hermann, T.N., 1990, Organic World Billion Year Ago: Nauka.

Hofmann, H.J., 1985, The mid-Proterozoic Little Dal macrobiota. Mackenzie Mountains, north-west Canada.: Paleontology, v. 28, p. 331-354.

Jefferson, C.W., and Parrish, R.R., 1989, Late Proterozoic stratigraphy, U-Pb zircon ages, and rift tectonics, Mackenzie Mountains, northwestern Canada: Canadian Journal of Earth Sciences, v. 26, p. 1784-1801.

Li, G., Chen, L., Pang, K., Zhou, G., Han, C., Yang, L., Lv, W., Wu, C., Wang, W., and Yang, F., 2020, An assemblage of macroscopic and diversified carbonaceous compression fossils from the Tonian Shiwangzhuang Formation in western Shandong, North China: Precambrian Research, v. 346, p. 105801, doi:10.1016/j.precamres.2020.105801.

Li, Y., Zhang, S., Hobbs, R., Caiado, C., Sproson, A.D., Selby, D., and Rooney, A.D., 2019, Monte Carlo sampling for error propagation in linear regression and 
applications in isochron geochronology: Science Bulletin, v. 64, p. 189-197, doi:10.1016/j.scib.2018.12.019.

Loron, C.C., François, C., Rainbird, R.H., Turner, E.C., Borensztajn, S., and Javaux, E.J., 2019, Early fungi from the Proterozoic era in Arctic Canada: Nature, v. 570, p. 232235, doi:10.1038/s41586-019-1217-0.

Loron, C.C., Rainbird, R.H., Turner, E.C., Greenman, J.W., and Javaux, E.J., 2018, Implications of selective predation on the macroevolution of eukaryotes: evidence from Arctic Canada: Emerging Topics in Life Sciences, v. 2, p. 247-255, doi:10.1042/etls20170153.

Ludwig, K.R., 1980, Calculation of Uncertainties of U-Pb Isotope Data: Earth and Planetary Science Letters, v. 46, p. 212-220.

Ludwig, K.R., 2011, Isoplot: A Plotting and Regression Program for Radiogenic Isotope Data.

Macdonald, F.A., Schmitz, M.D., Crowley, J.L., Roots, C.F., Jones, D.S., Maloof, A.C., Strauss, J. V., Cohen, P.A., Johnston, D.T., and Schrag, D.P., 2010, Calibrating the cryogenian: Science, v. 327, p. 1241-1243, doi:10.1126/science.1183325.

Milton, J.E., Hickey, K.A., Gleeson, S.A., and Friedman, R.M., 2017, New U-Pb constraints on the age of the Little Dal Basalts and Gunbarrel-related volcanism in Rodinia: Precambrian Research, v. 296, p. 168-180, doi:10.1016/j.precamres.2017.04.030.

Narbonne, G.M., and Hofmann, H.J., 1987, Ediacaran biota of the Wernecke Mountains, Yukon, Canada: Palaeontology, v. 30, p. 647-676.

Narbonne, G.M., Kaufman, A.J., and Knoll, A.H., 1994, Integrated chemostratigraphy and biostratigraphy of the Windermere Supergroup, northwestern Canada: implications for Neoproterozoic correlations and the early evolution of animals: Geological Society of America Bulletin, v. 106, p. 1281-1292, doi:10.1130/00167606(1994)106<1281:ICABOT>2.3.CO;2.

Narbonne, G.M., Laflamme, M., Trusler, P.W., Dalrymple, R.W., and Greentree, C., 2014, Deep-Water Ediacaran Fossils from Northwestern Canada: Taphonomy, Ecology, and Evolution: Journal of Paleontology, v. 88, p. 207-223, doi:10.1666/13053.

Nowell, G.M., Luguet, A., Pearson, D.G., and Horstwood, M.S.A., 2008, Precise and accurate $186 \mathrm{Os} / 188 \mathrm{Os}$ and $187 \mathrm{Os} / 188 \mathrm{Os}$ measurements by multi-collector plasma ionisation mass spectrometry (MC-ICP-MS) part I: Solution analyses: Chemical Geology, v. 248, p. 363-393, doi:10.1016/j.chemgeo.2007.10.020.

Rainbird, R.H., McNicoll, V.J., Thériault, R.J., Heaman, L.M., Abbott, J.G., Long, D.G.F., and Thorkelson, D.J., 1997, Pan-continental river system draining Grenville orogen recorded by $\mathrm{U}-\mathrm{Pb}$ and $\mathrm{Sm}-\mathrm{Nd}$ geochronology of Neoproterozoic quartzarenites and mudrocks, Northwestern Canada: Journal of Geology, v. 105, p. 1-17, doi:10.1086/606144.

Rasband, W.S., and U.S. National Institutes of Health, 1997, ImageJ:

Rooney, A.D., Strauss, J. V., Brandon, A.D., and Macdonald, F.A., 2015, A Cryogenian chronology: Two long-lasting synchronous neoproterozoic glaciations: Geology, v. 43, p. 459-462, doi:10.1130/G36511.1.

Selby, D., and Creaser, R.A., 2003, Re-Os geochronology of organic rich sediments: An evaluation of organic matter analysis methods: Chemical Geology, v. 200, p. 225- 
240, doi:10.1016/S0009-2541(03)00199-2.

Sharma, M., and Shukla, Y., 2012, Megascopic carbonaceous compression fossils from the neoproterozoic bhima basin, Karnataka, South India: Geological Society Special Publication, v. 366, p. 277-293, doi:10.1144/SP366.5.

Sharma, M., and Shukla, Y., 2009, Taxonomy and affinity of Early Mesoproterozoic megascopic helically coiled and related fossils from the Rohtas Formation, the Vindhyan Supergroup, India: Precambrian Research, v. 173, p. 105-122, doi:10.1016/j.precamres.2009.05.002.

Smoliar, M., Walker, R.J., and Morgan, J.W., 1996, Re-Os Ages of Group IIA , IIIA, IVA, and IVB Iron Meteorites: Science, v. 271, p. 1099-1102.

Strauss, J. V., Rooney, A.D., MacDonald, F.A., Brandon, A.D., and Knoll, A.H., 2014, $740 \mathrm{Ma}$ vase-shaped microfossils from Yukon, Canada: Implications for neoproterozoic chronology and biostratigraphy: Geology, v. 42, p. 659-662, doi:10.1130/G35736.1.

Tang, Q., Pang, K., Yuan, X., and Xiao, S., 2020, A one-billion-year-old multicellular chlorophyte: Nature Ecology and Evolution, v. 4, p. 1-7, doi:10.1038/s41559-0201122-9.

Tang, Q., Pang, K., Yuan, X., and Xiao, S., 2017, Electron microscopy reveals evidence for simple multicellularity in the Proterozoic fossil Chuaria: Geology, v. 45, p. 7578, doi:10.1130/G38680.1.

Thorkelson, D.J., 2000, Geology and mineral occurrences of the Slats Creek, Fairchild Lake and "Dolores Creek" areas, Wernecke Mountains (106D/16, 106C/13, 106C/14), Yukon Territory: Exploration and Geological Services Division, Yukon Region, Bulletin, v. 10, p. 1-73.

Turner, E.C., 2011, Stratigraphy of the Mackenzie Mountains supergroup in the Wernecke Mountains, Yukon, in MacFarlane, K.E., Weston, L.H., and Relf, C. eds., Yukon Exploration and Geology 2010, Yukon Geological Survey, p. 207-231.

Van Acken, D., Thomson, D., Rainbird, R.H., and Creaser, R.A., 2013, Constraining the depositional history of the Neoproterozoic Shaler Supergroup, Amundsen Basin, NW Canada: Rhenium-osmium dating of black shales from the Wynniatt and Boot Inlet Formations: Precambrian Research, v. 236, p. 124-131, doi:10.1016/j.precamres.2013.07.012.

Walter, M.R., Oehler, J.H., and Oehler, D.Z., 1976, Megascopic algae 1300 million years old from the Belt Supergroup , Montana: A reinterpretation of Walcott's Helminthoidichnites: Journal of Paleontology, v. 50, p. 872-881.

Wang, Y., Du, W., Komiya, T., Wang, X.L., and Wang, Y., 2015, Macroorganism paleoecosystems during the middle-late Ediacaran Period in the Yangtze Block, South China: Paleontological Research, v. 19, p. 237-250, doi:10.2517/2015pr009.

Xiao, S., and Dong, L., 2006, On the Morphological and Ecological History of Proterozoic Macroalgae, in Xiao, S. and Kaufman, A.J.. eds., Neoproterozoic Geobiology and Paleobiology, Dordrecht, v. 27, p. 57-83.

Xiao, S., and Tang, Q., 2018, After the boring billion and before the freezing millions: evolutionary patterns and innovations in the Tonian Period: Emerging Topics in Life Sciences, v. 2, p. 161-171, doi:10.1042/etls20170165.

Yukon Geologic Survey, 2018, Yukon Geological Survey Bedrock Geology Dataset:, http://data.geology.gov.yk.ca/Compilation/3\#InfoTab. 
Zhu, S., Zhu, M., Knoll, A.H., Yin, Z., Zhao, F., Sun, S., Qu, Y., Shi, M., and Liu, H., 2016, Decimetre-scale multicellular eukaryotes from the 1.56-billion-year-old Gaoyuzhuang Formation in North China: Nature Communications, v. 7, p. 1-8, doi:10.1038/ncomms 11500 . 